\title{
Pengaruh NPM, ROA, ROE terhadap Harga Saham pada Perusahaan LQ45
}

\author{
Kannia Aulia Sahari ${ }^{1}$ \\ Fakultas Ekonomi dan Bisnis \\ Universitas Udayana, Indonesia \\ Email: kannjune88@gmail.com
}

\author{
I Wayan Suartana ${ }^{2}$ \\ Fakultas Ekonomi dan Bisnis \\ Universitas Udayana, Indonesia
}

\begin{abstract}
ABSTRAK
Tujuan penelitian ini adalah un tuk mengetahui pergerakan harga saham yaitu analisis fundamenal dimana rasio profitabilitas yang sering digunakan dalam analisis fundamental yaitu NPM, ROA dan ROE. Penelitian ini dilakukan pada perusa haan yang terga bung da lam indeks LQ45 tahun 2014-2018 di Bursa Efek Indonesia. Populasi penelitian sebanyak 68 perusahaan. Sampel dipilih menggunakan teknik purposive sampling sehingga jumlah sa mpel yang diperoleh sebanyak 26 perusa ha an dan jumlah pengamatan selama 5 tahun adalah 130 a matan. Teknik a nalisis data men ggunakan a na lisis regresi linier berganda. Berda sarkan ha sil a nal isis ini menunjukkan ba hwa NPM dan ROA tidak berpengaruh pada harga saham sehingga tidak mampu meningkatkan harga saham pada perusaha an yang terga bung dalam indeks LQ45, sed an gkan ROE berpen garuh terh a dapharga sa ham sehingga semakin tinggi tingkat ROE maka semakin tinggi harga saham pada perusahaan yang tergabung dalam indeks LQ45.
\end{abstract}

Kata Kunci: NPM; ROA; ROE; Harga Saham.

\section{The Effect NPM, ROA, ROE On Stock Prices of LQ45 Company}

\section{ABSTRACT}

The purpose of this study is to determine the movement of stock prices, namely fundamental anal ysis where profitability ratios are often used inf undamental analysis, namely NPM, ROA and ROE. Th is research was conducted on companies in corporated in the 20142018 LQ45 index on the Indonesia S tock Exchange. The research pop ulation is 68 companies. Sa mples were selected using a purp osive sampling technique so that the number of samples ob tained was 26 companies and the number of observations over 5 years was 130 observations. Data analysis techniques using multiple linear regression analysis. Based on the results of this a nalysis show that NPMand ROA haveno effecton stock prices so that they are unable to increase share prices in companies incorporated in the $L Q 45$ index, while ROE affects stock prices so the higher the ROE level the higher the stock prices at companies incorporated in the $L Q 45$ index.

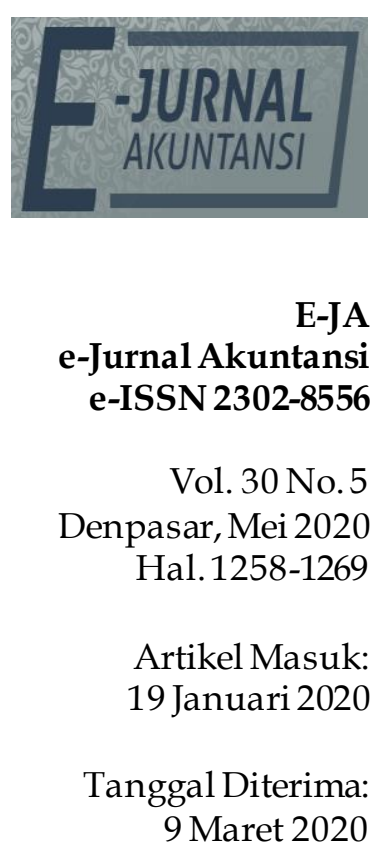

Keywords: $\quad$ NPM; ROA; ROE; Stock Price. 


\section{PENDAHULUAN}

Laporan keuangan pada perusahaan akan memberikan informasi kepada investor dalam mengambil keputusan berinvestasi. Prinsip dasar dalam berinvestasi salah satunya adalah "Buy what you know and know what you buy", artinya dalam berinvestasi, investor harus membeli produk investasi yang dikenali, dan diketahui perkiraan nilainya (Megasari, 2015). Investasi yang sering dilakukan di pasar modal adalah investasi saham. Saham merupakan bukti penyertaan modal di suatu perusahaan atau bukti kepemilikan atas suatu perusahaan.

Saham pada perusahaan dapat mengalami perubahan. Perubahan harga saham tid ak selalu positif namun dapat juga bernilai negatif, sehingga terbentuk pergerakan harga saham yang naik turun tidak beraturan. Selain hasil penjualan saham digunakan peru sahaan sebagai tambahan modal, pergerakan harga saham dimanfaatkan oleh para pelaku pasar untuk mendapatkan keuntungan dari hasil jual dan beli saham (Hek \& Widya, 2014). Saham perusahaan yang berfluktuasi, tingginya tingkat likuiditas dan kapi talitas pasar akan tergabung dalam indeks LQ45.

Indeks LQ45 sebagai pelengkap IHSG, meny ediakan sarana obyektif dan terperca ya bagi analisis keuangan, manajer investasi dan investor (Rachmawati, 2018). Saham-saham yang termasuk dalam perhitungan indeks LQ45 secara rutin dipantau perkembangan kinerjanya. Setiap tiga bulan sekali dilakukan evaluasi atas pergerakan urutan saham-saham yang digunakan dalam perhitungan ind eks, sementara pergantian saham yang tidak memenuhi kriteria akan dilakukan setiap enam bulan sekali yaitu pada aw al bulan Februari dan Agustus.

Salah satu analisis yang sering dig unakan yakni analisis fundamental. Analisis fund amental ad alah ana lisis penentu nilai seperti prospek pendapatan yang dihasilkan oleh perusahaan yang dilihat dari prospek ekonomi negara serta lingkungan bisnis perusahaan tersebut untuk mencari harga saham wajar (Bodie \& Marcus, 2014 : 237). Analisis fundamental terd apat analisis rasio keuangan, dimana salah satu analisis rasio keuangan yaitu rasio profitabilitas yang mengukur NPM, ROA dan ROE.

Net Profit Margin (NPM) merupakan ra sio yang meng ukur bera pa besar persentase dari penjualan setelah bunga dan pajak. Semakin tinggi NPM maka akan mempengaruhi tingkat kinerja perusa haan yang menyebabkan perusahaan semakin baik dan dapat meningkatkan harga saham perusahaan, sehingga akan menimbulkan kepercayaan investor untuk menanamkan modal pada perusahaan (Stoner \& Sirait, 1994 : 126). Kasus yang dikutip dari Detikfinance, Selasa (18/6/2019) PT. Bukit Asam Tbk (PTBA) membagikan dividen tunai sebesar Rp 601,86 miliar atau Rp 285,5 per saham untuk tahun buku 2016. Jumlah dividen tunai yang dibagikan itu merupakan 30\% dari total laba tahun buku 2016 sebesar Rp 2,01 triliun. Total dividen per saham tahun buku 2016 itu sebesar $98,54 \%$ dibanding dividen per saham tahun buku sebelumnya sebesar Rp 289,73. Pada saat yang sama, tingkat perolehan laba bersih NPM PTBA tahun 2016 tercatat sebesar 14,34\%. Berdasarkan laporan lembaga kajian keuangan ind ependen Bloomberg ed isi Maret 2017, an gka tersebut merupakan NPM ter tinggi di antara seluruh perusahaan ta mbang batu bara nasional serta 
peningkatan harga saham yaitu tercatat Rp 4.150 pada bulan Februari menjadi Rp 4.250 pada bulan Maret.

Return On Asset (ROA) adalah perbandingan antara laba bersih setelah pajak dengan aktiva untuk mengukur tingkat pengambilan investasi total. Semakin tinggi ROA suatu perusahaan, semakin besar pula tingkat keuntungan yang dicapai oleh perusahaan. ROA perlu dipertimbangkan oleh investor dalam berinvestasi saham, karena ROA berperan sebagai indikator efisiensi perusahaan dalam menggunakan aset untuk memperoleh laba (Stoner \& Sirait, 1994 : 126).

Return On Equity (ROE) adalah kemampuan perusahaan menghasilkan laba atas total ekuitas yang dimilikinya. ROE dapat diperoleh dengan cara membandingkan laba setelah pajak dengan total ekuitas perusahaan. Tingkat ROE yang tinggi menunjukan bahwa perusahaan dapat menghasilkan laba bersih yang tinggi, kinerja keuangan perusahaan akan dianggap baik apabila laba bersih perusahaan tersebut tinggi. ROE juga digunakan investor untuk mengukur kinerja dan risiko dalam mengambil keputusan berinvestasi. Mengutip dari Detikfinance, Selasa (18/6/2019) PT. Unilever Indonesia Tbk (UNVR) mencatat kinerja yang bersinar di tahun 2008. Meski mengalami rugi derivatif perusahaan bisa mengatasinya. Unilever terbukti menjadi perusahaan yang paling efisien. Unilever berhasil meningkatkan laba bersih sebesar $23 \%$ di tahun 2008 menjadi Rp 2,4 triliun. Penjualan tumbuh 24\% menjadi Rp 15,5 triliun yang terdongkrak oleh kenaikan harga jual sebesar $14 \%$ dan volume penjualan yang meningkat. Marjin kotor turun menjadi 49\% di 2008 dari 50\% di tahun 2007 disebabkan kenaikan harga komoditas dan depresiasi rupiah. Marjin operasional stabil di 22\%. Rugi derivatif yang sebesar Rp 60 miliar (terutama dari transaksi lindung nilai) berhasil diatasi dengan income tax refund yang sebesar Rp 32 miliar. PT. Danareksa juga menyatakan, ROE dan ROA unilever selalu tinggi. Rabu (15/4/2009) harga saham UNVR naik Rp 100 menjadi Rp 7.800 per saham.

Menurut Houston \& Brigham (2008 : 91) isyarat atau sinyal adalah suatu tindakan yang diambil perusahaan untuk memberi petunjuk bagi investor tentang bagaimana manajemen memandang prospek perusahaan. Sinyal ini berupa informasi mengenai apa yang sudah dilakukan oleh manajemen untuk merealisasikan keinginan pemilik. Informasi yang dikeluarkan oleh perusahaan merupakan hal yang penting, karena pengaruhnya terhadap keputusan investasi pihak diluar perusahaan. Informasi tersebut penting bagi investor dan pelaku bisnis karena informasi pada hakekatnya menyajikan keterangan, catatan atau gambaran, baik untuk keadaan masa lalu, saat ini maupun masa yang akan datang bagi kelangsungan hidup perusahaan dan bagaimana efeknya pada perusahaan.

Teori sinyal menjelaskan mengapa perusahaan mempuyai dorongan untuk memberikan informasi laporan keuangan pada pihak eksternal. Dorongan perusahaan untuk memberikan informasi karena terdapat asimetri informasi antara perusahaan dan pihak luar karena perusahaan mengetahui lebih banyak mengenai perusahaan dan prospek yang akan datang daripada pihak luar yaitu investor dan kreditor. Informasi yang kurang bagi pihak luar mengenai perusahaan menyebabkan mereka melindungi diri mereka dengan memberikan harga yang rendah untuk perusahaan. Perusahaan dapat meningkatkan nilai perusahaan dengan mengurangi informasi asimetri. Salah satu cara untuk 
mengurangi informasi asimetri adalah dengan memberikan sinyal pada pihak luar (Zaenal, 2005 : 11).

Harga saham adalah nilai surat saham yang mencerminkan kekayaan perusahaan yang mengeluarkan saham tersebut, dimana perubahan dan fluktuasinya sangat ditentukan oleh kekuatan permintaan dan penawaran yang terjadi di pasar bursa (Putri, 2015). Informasi yang berkaitan dengan dinamika harga saham perlu diketahui sebelum para investor berinvestasi agar dapat mengambil keputusan tentang saham yang layak dipilih untuk berinvestasi.

Teori sinyal menyatakan bahwa pihak eksekutif perusahaan memiliki informasi lebih baik mengenai perusahaannya sehingga perusahaan terpacu untuk menyampaikan informasi tersebut kepada calon investor agar harga saham perusahaannya meningkat. Informasi yang didapat oleh investor salah satunya aktivitas penjualan yang menghasilkan laba. Aktivitas tersebut dihitung berdasarkan NPM. Investor akan tertarik dengan NPM yang tinggi karena menunjukkan kinerja perusahaan yang dapat menghasilkan laba bersih yang besar melalui aktivitas penjualannya sehingga saham perusahaan tersebut banyak diminati investor dan akan menaikkan harga saham perusahaan tersebut (Sianipar, 2005). Penelitian Hendri (2015) memperoleh hasil NPM berpengaruh positif pada harga saham selaras dengan penelitian (Salim et al, 2016) yang menunjukkan bahwa NPM berpengaruh terhadap harga saham. Berdasarkan hal ini maka hipotesis penelitian, yaitu:

$\mathrm{H}_{1}$ : NPM berpengaruh positif pada harga saham.

Teori sinyal menyatakan pada sinyal positif dapat dijadikan sinyal untuk para investor dalam memprediksi seberapa besar perubahan harga saham yang dimiliki. Sinyal positif yang diterima investor salah satunya ROA. Informasi berupa ROA, tingkat pengembalian terhadap aset dan laba yang didapat dari aset yang digunakan. Apabila ROA tinggi maka akan menjadi sinyal yang baik bagi para investor. Investor akan tertarik untuk menginvestasikan dananya yang berupa surat berharga atau saham apabila ROA tinggi dan kinerja keuangan perusahaan tersebut baik. Penelitian Gerald et al., (2017), memperoleh hasil ROA berpengaruh positif pada harga saham selaras dengan penelitian Akhmadi \& Prasetyo (2018) serta Muhlis et al., (2019), yang menunjukkan bahwa ROA berpengaruh terhadap harga saham. Berdasarkan hal ini maka hipotesis penelitian, yaitu:

$\mathrm{H}_{2}$ : ROA berpengaruh positif pada harga saham.

Teori sinyal menyatakan perusahaan menghindari terjadinya asimetri informasi sehingga mempunyai dorongan untuk memberikan informasi laporan keuangan kepada investor. Tingkat ROE yang tinggi akan mendorong para manager untuk memberikan informasi lebih terperinci. Para manajer ingin meyakinkan para investor bahwa perusahaan mampu menghasilkan profitabilitas yang baik. Investor akan sangat terbantu dengan melakukan analisis rasio ROE dalam mengambil keputusan. Semakin tinggi nilai ROE maka akan semakin tinggi pula harga saham, karena return atau penghasilan yang diperoleh pemilik perusahaan akan semakin tinggi sehingga harga saham perusahaan akan meningkat. ROE berpengaruh positif pada harga saham karena semakin tinggi ROE maka semakin tinggi harga saham. Penelitian Arifin et al., (2019), memperoleh hasil ROE berpengaruh positif pada harga saham selaras 
dengan penelitian Sondakh et al., (2019) dan Hadi (2018). Berdasarkan hal ini maka hipotesis penelitian, yaitu:

$\mathrm{H}_{3}$ : ROE berpengaruh positif pada Harga Saham.

\section{METODE PENELITIAN}

Pendekatan yang dilakukan dalam penelitian ini merupakan pendekatan kuantitatif berbentuk asosiatif yaitu penelitian yang menyatakan hubungan dua variabel atau lebih. Penelitian ini bertujuan untuk menguji pengaruh NPM, ROA, ROE terhadap harga saham pada perusahaan yang tercantum dalam Indeks LQ45. Kajian pustaka terdiri dari teori yang mendukung penelitian ini NPM adalah perbandingan antara laba bersih dengan penjualan. Semakin besar NPM, maka kinerja perusahaan akan semakin produktif, sehingga akan meningkatkan kepercayaan investor untuk menanamkan modalnya pada perusahaan (Hadi, 2018). NPM dihitung menggunakan rumus:

NPM $=\frac{\text { Laba bersih setelah pajak }}{\text { Penjwalan }} \times 100 \%$

ROA adalah rasio digunakan untuk mengukur kemampuan perusahaan dalam menghasilkan laba yang berasal dari aktivitas investasi. Menurut Houston \& Brigham (2008 : 91) rasio ini digunakan untuk mengukur kemampuan manajemen dalam memperoleh laba secara keseluruhan. Semakin besar ROA, semakin besar pula tingkat keuntungan yang dicapai oleh perusahaan tersebut dan semakin baik pula posisi perusahaan tersebut dari segi penggunaan aset. ROA dihitung menggunakan rumus:

ROA $=\frac{\text { Laba Bersih }}{\text { Total Aktiva }} \times 100 \%$

ROE adalah perbandingan antara laba bersih dengan modal perusahaan ROE adalah rasio yang langsung menghitung pengembalian terhadap ekuitas yang ditanamkan oleh investor. ROE yang meningkat tentu meningkatkan permintaan terhadap saham dari perusahaan terkait, sehingga nilai dari perusahaan pun ikut terdongkrak (Hamidy, 2015). ROE dihitung menggunakan rumus:

ROE $=\frac{\text { Laba setelah pajak }}{\text { Total Ekuitas }} \times 100 \%$

Harga saham adalah harga yang terjadi di pasar bursa pada saat tertentu yang ditentukan oleh pelaku pasar dan ditentukan oleh permintaan dan penawaran saham yang bersangkutan di pasar modal (Kurnia \& N Fitriani, 2015).

Penelitian ini menggunakan purposive sampling. Menurut Sugiyono (2013: 82) purposive sampling adalah teknik pengambilan sampel sumber data dengan pertimbangan tertentu. Berdasarkan metode tersebut maka kriteria penentuan sampel yang digunakan dalam penelitian ini yaitu perusahaan yang terdaftar pada indeks LQ45 selama tahun 2014-2018 dan perusahaan dalam periode penelitian 2014-2018 yang tidak mengalami delisting dari indeks LQ45. Delisting disebabkan karena saham suatu perusahaan mengalami penurunan kinerja sehingga tidak lagi memenuhi persyaratan pencatatan Perusahaan dapat mengajukan permohonan untuk penghapusan pencatatan perusahaannya yang disebut dengan voluntary delisting. Data sekunder yang digunakan dalam penelitian ini adalah data time series rentang waktu 2014-2018 dan laporan 
keuangan perusahaan LQ45 yang terdaftar di Bursa Efek Indonesia dan dapat diperoleh dengan cara mendownload melalui internet dari situs resmi dengan alamat www.idx.co.id

\section{HASIL DAN PEMBAHASAN}

Data penelitian diperoleh dari 68 perusahaan yang terdaftar di Indeks LQ45 dari periode 2014-2018. Perusahaan LQ45 yang terdaftar di BEI mengalami delisting sebanyak 42 perusahaan dari periode 2014-2018. Teknik sampling yang digunakan yaitu teknik purposive sampling sehingga jumlah perusahaan yang dijadikan sampel sebanyak 26 perusahaan dan jumlah observasi selama 5 tahun sebanyak 130 amatan yang memenuhi kriteria untuk dianalisis. Hasil uji statistik deskriptif variabel penelitian, terdapat berbagai informasi deskripsi dan variabel yang digunakan yaitu harga saham yang memiliki nilai terendah (minimum) sebesar Rp 366 per lembar saham pada perusahaan PT. Lippo Karawaci Tbk dengan kode saham LPKR tahun 2018 dan nilai tertinggi (maksimum) sebesar Rp 75.150 per lembar saham pada perusahaan PT. Gudang Garam Tbk dengan kode saham GGRM tahun 2018. Nilai rata-rata (mean) data variabel harga saham sebesar 9728,2308. Standar deviasi sebesar 14446,76660. NPM yang memiliki nilai terendah (minimum) sebesar 2,34 pada perusahaan PT. Adhi Karya Tbk dengan kode saham ADHI tahun 2018 dan nilai tertinggi (maksimum) sebesar 71,73 pada perusahaan PT. Bumi Serpong Damai Tbk dengan kode saham BSDE tahun 2014. Nilai rata-rata (mean) data variabel NPM sebesar 15,9986. Standar deviasi sebesar 11,27027. ROA yang memiliki nilai terendah (minimum) sebesar 0,27 pada perusahaan PT. Adhi Karya Tbk dengan kode saham ADHI tahun 2018 dan nilai tertinggi (maksimum) sebesar 40,18 pada perusahaan PT. Unilever Indonesia Tbk dengan kode saham UNVR tahun 2014. Nilai rata-rata (mean) data variabel ROA sebesar 7,4765. Standar deviasi sebesar 7,26577. ROE yang memiliki nilai terendah (minimum) sebesar 0,60 pada perusahaan PT. Lippo Karawaci Tbk dengan kode saham LPKR tahun 2018 dan nilai tertinggi (maksimum) sebesar 135,85 pada perusahaan PT. Unilever Indonesia Tbk dengan kode saham UNVR tahun 2016. Nilai rata-rata (mean) data variabel ROE sebesar 17,5662. Standar deviasi sebesar 21,56898.

Hasil uji normalitas menunjukkan bahwa nilai Asymp. Sig. (2-tailed) yang dihasilkan adalah sebesar 0,083. Nilai yang dihasilkan ini lebih besar dari signifikan 0,05 sehingga dapat disimpulkan bahwa data mengikuti sebaran normal. Oleh karena itu asumsi normalitas pada terpenuhi. Hasil uji multikolinieritas menunjukkan bahwa untuk semua variabel independen yang digunakan memiliki nilai tolerance lebih besar dari 0,10, NPM $\left(X_{1}\right)$ sebesar 0,832, ROA $\left(X_{2}\right)$ sebesar 0,377 dan ROE $\left(X_{3}\right)$ sebesar 0,338 . Nilai VIF yang dihasilkan lebih kecil dari 10, NPM $\left(X_{1}\right)$ sebesar 1,202, ROA $\left(X_{2}\right)$ sebesar 2,652 dan ROE $\left(X_{3}\right)$ sebesar 2,956 sehingga dapat disimpulkan bahwa tidak terjadi multikolinieritas antar variabel independen. Oleh karena itu asumsi multikolinieritas telah terpenuhi. Hasil uji heteroskedastisitas menunjukkan hasil bahwa semua variabel bebas yang digunakan pada penelitian NPM $\left(X_{1}\right)$ sebesar 0,613 , ROA $\left(X_{2}\right)$ sebesar 0,600 dan ROE $\left(X_{3}\right)$ sebesar 0,644 memiliki nilai lebih besar dari 0,05 sehingga dapat disimpulkan bahwa tidak terjadi heteroskedasitas. Hasil uji autokorelasi menunjukan nilai Durbin Watson (DW) sebesar 1,858. Tabel Durbin- 
Watson dengan jumlah sampel (N) 130 dan banyak variabel bebas 3 diperoleh nilai upper boung $(\mathrm{dU})$ sebesar 1,761 dan 4-dU sebesar 2,239. Oleh karena nilai $\mathrm{dU}<\mathrm{DW}<(4-\mathrm{dU})$ yaitu $(1,761<1,858<2,239)$, maka dapat disimpulkan bahwa model regresi dalam penelitian tidak terdapat autokorelasi antar residual

Tabel 1. Hasil Regresi Linier Berganda

\begin{tabular}{|c|c|c|c|c|c|}
\hline \multirow[b]{2}{*}{ Model } & \multicolumn{2}{|c|}{$\begin{array}{l}\text { Unstandardized } \\
\text { Coefficients }\end{array}$} & \multirow{2}{*}{$\begin{array}{l}\text { Standardized } \\
\text { Coefficients } \\
\text { Beta }\end{array}$} & \multirow[t]{2}{*}{ t } & \multirow[t]{2}{*}{ Sig. } \\
\hline & $\bar{B}$ & Std. Error & & & \\
\hline (Constant) & 7,149 & 0,412 & & 17,368 & 0.000 \\
\hline NPM (X1) & $-0,063$ & 0,149 & $-0,038$ & $-0,422$ & 0,674 \\
\hline $\mathrm{ROA}\left(\mathrm{X}_{2}\right)$ & 0,070 & 0,166 & 0,056 & 0,425 & 0,672 \\
\hline RO.E (X3) & 0,541 & 0,206 & 0,369 & 2,631 & 0,010 \\
\hline
\end{tabular}

$\begin{array}{ll}\text { Adjusted R Square } & 0,142 \\ \text { F Hitung } & 8,090 \\ \text { Signifikans.i F } & 0,000\end{array}$

Sumber: Data Penelitian, 2019

Berdasarkan hasil analisis regresi linier berganda seperti yang disajikan pada Tabel 1. maka dapat dibuat persamaan regresi sebagai berikut:

$$
\mathrm{Y}=7,149-0,063 \mathrm{X}_{1}+0,070 \mathrm{X}_{2}+0,541 \mathrm{X}_{3}
$$

Berdasarkan model persamaan regresi tersebut dapat dijelaskan yaitu nilai koefisien regresi NPM $\left(\mathrm{X}_{1}\right)$ sebesar $-0,063$ memiliki arti bahwa apabila variabel NPM mengalami peningkatan dalam penerapannya, maka harga saham akan menurun dengan asumsi variabel bebas lainnya konstan atau tidak mengalami perubahan. Nilai koefisien $\operatorname{ROA}\left(X_{2}\right)$ sebesar 0,070 memiliki arti bahwa apabila variabel ROA mengalami peningkatan dalam penerapannya, maka harga saham akan meningkat dengan asumsi variabel bebas lainnya konstan atau tidak mengalami perubahan. Nilai koefisien $\operatorname{ROE}\left(X_{3}\right)$ sebesar 0,541 memiliki arti bahwa apabila variabel ROE mengalami peningkatan dalam penerapannya, maka harga saham akan meningkat dengan asumsi variabel bebas lainnya konstan atau tidak mengalami perubahan.

Hasil uji koefisien determinasi $\left(\mathrm{R}^{2}\right)$ didapat nilai adjusted $\mathrm{R}^{2}$ (koefisien determinasi yang telah disesuaikan adalah sebesar 0,142 atau 14,2\%. Hal ini mengindikasikan bahwa sebesar $14,2 \%$ harga saham $(\mathrm{Y})$ mempengaruhi variabel $\operatorname{NPM}\left(X_{1}\right)$, ROA $\left(X_{2}\right)$ dan $\operatorname{ROE}\left(X_{3}\right)$ sedangkan sisanya sebesar 85,8 persen dijelaskan oleh faktor-faktor lain yang tidak dijelaskan dalam model penelitian ini. Hasil uji signifikansi F sebesar 0,000 nilai ini lebih kecil dari 0,05, sehingga dapat disimpulkan bahwa terdapat pengaruh signifikan NPM $\left(X_{1}\right), \operatorname{ROA}\left(X_{2}\right)$ dan ROE $\left(X_{3}\right)$ terhadap variabel terikat yaitu harga saham $(Y)$ secara simultan.

Hasil uji $\mathrm{t}$ menunjukkan secara parsial dengan menggunakan uji $\mathrm{t}$ diperoleh nilai signifikan sebesar 0,674 nilai ini lebih besar dari 0,05 sehingga dapat disimpulkan bahwa tidak terdapat pengaruh signifikan secara parsial antara NPM $\left(X_{1}\right)$ terhadap harga saham $(Y)$. Hal ini mengindikasikan hipotesis 1 yang menyatakan NPM berpengaruh positif terhadap harga saham ditolak. Setelah diuji secara parsial dengan menggunakan uji t diperoleh nilai signifikan sebesar 0,672 nilai ini lebih besar dari 0,05 sehingga dapat disimpulkan bahwa tidak terdapat pengaruh signifikan secara parsial antara $\mathrm{ROA}\left(\mathrm{X}_{2}\right)$ terhadap 
harga saham $(Y)$. Hal ini mengindikasikan hipotesis 2 yang menyatakan ROA berpengaruh positif terhadap harga saham ditolak. Setelah diuji secara parsial dengan menggunakan uji t diperoleh nilai signifikan sebesar 0,010 nilai ini lebih kecil dari 0,05 sehingga dapat disimpulkan bahwa terdapat pengaruh signifikan secara parsial antara $\operatorname{ROE}\left(\mathrm{X}_{3}\right)$ terhadap harga saham $(\mathrm{Y})$. Hal ini mengindikasikan hipotesis 3 yang menyatakan ROE berpengaruh positif terhadap harga saham diterima.

Berdasarkan hasil penelitian pada Tabel 1. Coefficients menunjukkan bahwa nilai koefisien variabel NPM $\left(X_{1}\right)$ sebesar $-0,063$ maka artinya apabila nilai $\operatorname{NPM}\left(X_{1}\right)$ naik satu satuan maka harga saham $(Y)$ akan turun sebesar 0,063 sehing ga dapat disimpulkan bahwa NPM $\left(X_{1}\right)$ ber pengaruh negatif ter hadap harga saham $(Y)$ dan setelah diuji secara parsial dengan menggunakan uji $t$, diperoleh nilai T hitung sebesar -0,422, nilai T hitung ini lebih kecil dari nilai $\mathrm{T}$ tabel sebesar 2,030. Nilai signifikan sebesar 0,674 nilai ini lebih besar dari 0,05 sehingga dapat disimpulkan bahwa tidak terdapat pengaruh signifikan secara parsial antara NPM $\left(\mathrm{X}_{1}\right)$ terhadap harga saham $(\mathrm{Y})$. Hasil penelitian menyatakan bahwa NPM $\left(X_{1}\right)$ tidak berpengar uh terhadap harga saham $(Y)$. Hasil penelitian ini sejalan dengan hasil penelitian Megasari (2015), Salim et al., (2016), Mangeta et al., (2019) menyatakan bahwa NPM tidak berpengaruh terhad ap harga saham.

Berdasarkan hasil penelitian pada Tabel 1. Coefficients menunjukkan bahwa nilai koefisien variabel $\mathrm{ROA}\left(\mathrm{X}_{2}\right)$ bernilai positif sebesar 0,070 maka artinya apabila nilai ROA $\left(\mathrm{X}_{2}\right)$ naik satu satuan maka harga saham $(\mathrm{Y})$ akan naik sebesar 0,070 sehingga da pat disimpulkan bahwa ROA $\left(X_{2}\right)$ berpengaruh positif terhadap harga saham $(\mathrm{Y})$ dan setelah diuji secara parsial dengan menggunakan Uji $\mathrm{T}$, diperoleh nilai $\mathrm{T}$ hitung sebesar 0,425 , nilai $\mathrm{T}$ hitung ini lebih kecil dari nilai T tabel sebesar 2,030. Nilai signifikan sebesar 0,672 nilai ini lebih besar dari 0,05, sehingga dapat disimpulkan bahwa tidak terdapat pengaruh signifikan secara parsial antara $\operatorname{ROA}\left(\mathrm{X}_{2}\right)$ terhadap harga saham $(\mathrm{Y})$. Sehingga dapat disimpulkan bahwa ROA $\left(X_{2}\right)$ tidak berpengaruh terhadap harga saham $(Y)$. Hasil penelitian ini sejalan dengan hasil penelitian Dewi et al., (2018), Ifani et al., (2019) dan Paradita et al., (2017) menyatakan bahwa ROA tidak berpengaruh terhadap harga saham.

Berdasarkan hasil penelitian pada Tabel 1. Coefficients menunjukkan bahwa nilai koefisien variabel $\operatorname{ROE}\left(X_{3}\right)$ bernilai positif sebesar 0,541 maka artinya apabila nilai $\operatorname{ROE}\left(\mathrm{X}_{3}\right)$ naik satu satuan maka harga sa ham $(\mathrm{Y})$ akan naik sebesar 0,541 , sehingga dapat disimpulkan bahwa ROE $\left(X_{3}\right)$ berpengaruh positif terhadap harga saham $(Y)$ dan setelah diuji secara parsial dengan menggunakan Uji T, diperoleh nilai T hitung sebesar 2,631, Nilai $\mathrm{T}$ hitung ini lebih besar dari nilai $\mathrm{T}$ table sebesar 2,030. Nilai signifikan sebesar 0,010 nilai ini lebih kecil dari 0,05 sehingga dapat disimpulkan bahwa terdapat pengaruh signifikan secara parsial antara ROE $\left(\mathrm{X}_{3}\right)$ terhadap harga saham $(\mathrm{Y})$. Sehingga dapat disimpulkan bahwa $\operatorname{ROE}\left(\mathrm{X}_{3}\right)$ berpengaruh positif signifikan terhadap harga saham $(Y)$. Hasil penelitian ini sejalan dengan hasil penelitian Arifin et al., (2019), Sondakh et al., (2019) dan Hadi (2018) menyatakan bahwa ROE berpengaruh terhadap harga saham. 
Hasil penelitian ini mampu memberikan kontribusi mengenai pengaruh NPM, ROA, ROE terhadap harga saham yang didukung oleh teori sinyal. Teori sinyal menyatakan bagaimana suatu perusahaan mencegah asimetri informasi dengan cara memberikan sinyal berupa informasi kepada para calon investor dalam pengambilan keputusan saat melakukan investasi.

Penelitian memberikan hasil NPM tidak berpengaruh terhadap harga saham yang menunjukkan bahwa investor cenderung kurang memperhatikan NPM sebagai rasio yang dapat dipertimbangkan dalam keputusan investasi mereka. Hal tersebut menunjukkan bahwa investor kurang percaya terhadap pengelolaan efisiensi kinerja operasional perusahaan. Dampak dari suku bunga acuan, inflasi, dan produk domestik bruto merupakan faktor lain yang mempengaruhi harga saham. Sehingga naik maupun turunnya NPM tidak mempengaruhi harga saham

Penelitian ini memberikan hasil ROA tidak berpengaruh terhadap harga saham. Perusahaan memiliki praktek akuntansi yang berbeda-beda menyebabkan perbandingan dalam penilaian persediaan antara perusahaan satu dengan perusahaan lainnya. Perbedaan metode penilaian persediaan seperti First In First Out (FIFO), Last In First Out (LIFO), dan method of average yang digunakan akan berpengaruh pada nilai persediaan dan jumlah aktiva. Faktor lain seperti aksi korporasi yang terdiri dari merger, akuisisi, right issue dan kebijakan pemerintah juga menjadi pengaruh lain terhadap harga saham. Sehingga naik maupun turunnya ROA tidak berpengaruh terhadap harga saham.

Penelitian ini memberikan hasil ROE berpengaruh signifikan terhadap harga saham. Hal ini sejalan dengan teori sinyal yang menyatakan perusahaan menghindari terjadinya asimetri informasi sehingga mempunyai dorongan untuk memberikan informasi laba bersih atas ekuitas kepada investor. Semakin meningkat ROE maka nilai perusahaan akan meningkat pula. Penelitian ini diharapkan dapat memberikan informasi dan menjadi pertimbangan dalam pengambilan keputusan bagi calon investor yang ingin berinvestasi. Hasil dari penelitian ini juga diharapkan dapat berkontribusi dan memberikan tambahan informasi bagi pihak yang berkepentingan serta dapat dijadikan referensi kepada peneliti lain yang ingin melakukan penelitian dengan topik yang sama.

\section{SIMPULAN}

Berdasarkan hasil penelitian dan hasil pembahasan dapat disimpulkan bahwa NPM tidak berpengaruh terhadap harga saham. Hal ini menunjukkan bahwa meningkat atau menurunnya NPM sebagai perbandingan antara laba bersih dengan penjualan tidak memiliki pengaruh pada harga saham perusahaan. ROA tidak berpengaruh terhadap harga saham. Hal ini menunjukkan bahwa meningkat atau menurunnya ROA sebagai pengukur kemampuan perusahaan dalam menghasilkan laba dari aktiva tidak memiliki pengaruh pada harga saham perusahaan. ROE berpengaruh positif terhadap harga saham. Hal ini menunjukkan bahwa meningkatnya efektivitas dan efisiensi pengelolaan ekuitas perusahaan dalam menghasilkan laba akan meningkatkan harga saham perusahaan begitu pula sebaliknya.

Bagi investor yang ingin melakukan analisis fundamental dalam menentukan harga saham disarankan untuk menggunakan rasio ROE dalam 
pertimbangannya. Hal ini dikarenakan hasil dari penelitian ini yang menunjukkan bahwa ROE berpengaruh terhadap harga saham. Investor tetap dapat memperhatikan NPM dan ROA namun sebagai penentu tingkat menghasilkan laba atas penjualan dan aktiva.

Bagi peneliti selanjutnya diharapkan untuk mengkaji lebih banyak sumber maupun referensi terkait NPM, ROA, ROE dan harga saham agar hasil penelitian berikutnya dapat menjadi lebih baik dan lebih lengkap. Selain itu penelitian ini masih berbasis periode tahunan sehingga untuk penelitian selan.jutnya disarankan untuk menggunakan periode triwulan dengan mengacu pada laporan keuangan triwulan perusahaan agar dapat meningkatkan tingkat akurasi dalam penelitian karena harga saham yang dapat berubah-ubah setiap waktunya.

\section{REFERENSI}

Abraham. (2017). Earnings Yield as a Predictor of Return on Assets, Return on Equity, Economic Value Added and the Equity Multiplier. Modern Economy, $8,10$.

Ahmed. (2019). Stock Return Volatility and Capital Structure Measures of Nonfinancial Firms in a Dynamic Panel Model: Evidence from Pakistan. International Journal of Finance and Economics, 24, 604.

Akhmadi, A., \& Prasetyo, A. R. (2018). Profitabilitas, Rasio Solvabilitas dan Harga Saham; Studi Empirik Pada Perusahaan Subsektor Batubara Yang Terdaftar Di Bursa Efek Indonesia Periode 2010-2014. Jurnal Riset Akuntansi Terpadu, 11, 61-71.

Arifin. (2019). Pengaruh Return On Equity (ROE) dan Earning Per Share (EPS) Terhadap Harga Saham Pada Perusahaan Makanan dan Minuman yang Terdaftar Di Bursa Efek Indonesia Tahun 2014-2016. Journal of Accounting.

Bodie, K., \& Marcus. (2014). Manajemen Portofolio dan Investasi.

Dewi, K, A., Purnomo, H., Murniati, W. (2018). Pengaruh Return On Assets (ROA), Return On Equity (ROE), dan Economic Value Added (EVA) Terhadap Harga Saham Perusahaan yang Tergabung dalam Jakarta Islamic Index Periode 2014 - 2016. Jurnal Riset Akuntansi, 1, 1-7.

Gerald, E. (2017). Pengaruh Return On Asset (ROA), Return On Equity (ROE), Net Profit Margin (NPM), dan Earning Per Share (EPS) Terhadap Harga Saham Perusahaan Yang Tergabung Dalam LQ45. Jurnal Ekonomi Manajemen Dan Bisnis, 5, 105-114.

Hadi, W. (2018). Analysis Of The Effect Of Net Profit Margin, Return On Assets And Return On Equity On Stock Price (Case Study on Consumption Industrial Sector Companies Listed in Indonesian Sharia Stock Index at Indonesia Stock Exchange in 2016). The Management Journal of Binaniaga, 3, 81.

Hakki, O. (2017). The Relationship Between Earnings-to-Price, Current Ratio, Profit Margin and Return: An Empirical Analysis on Istanbul Stock Exchange. Accounting and Finance Research, 7, 109.

Halaweh, M. (2018). An original information systems research method: The discount focus subgroup method. Electronic Journal of Business Research Methods, 16(1), 11-24. 
Hamidy. (2015). Pengaruh Struktur Modal Terhadap Nilai Perusahaan Dengan Profitabilitas Sebagai Variabel Intervening Pada Perusahaan Properti Dan Real Estate Di Bursa Efek Indonesia. Jurnal Manajemen Unud, 10, 665.

Hek, T. ., \& Widya, S. (2014). Pengaruh Price Earning Ratio, Return On Asset, Dan Current Ratio Terhadap Harga Saham Pada Perusahaan Dagang Yang Terdaftar Abstrak. Jurnal Akuntansi.

Hendri, E. (2015). Pengaruh Debt to Asset Ratio (DAR), Long Term Debt to Equity Ratio (LTDER) dan Net Profit Margin (NPM) Terhadap Harga Saham Pada Perusahaan Perbankan Yang Terdaftar di Bursa Efek Indonesia. Jurnal Akuntansi.

Hla, D., \& Teru, S. P. (2015). 15A. Efficiency of Accounting Information System and Performance Measures - Literature Review. International Journal of Accounting Information System, 3(May 2017), 976-984. https://doi.org/10.1016/j.cub.2007.10.043

Houston, J. ., \& Brigham, E. F. (2008). Dasar Dasar Manajemen Keuangan.

Idawati, \& Wahyudi, A. (2015). Effect of Earning Per Share (EPS) and Return On Assets (ROA) Against Share Price on Coal Mining Company Listed in Indonesia Stocks Exchange. Journal of Resource Development and Management, 79-92.

Ifani, P, A., Fujianti, L., Astuti, S, B. (2019). (2019). Pengaruh Profitabilitas, Leverage, dan Ukuran Perusahaan Terhadap Harga Saham Antara Indonesia dan Malaysia. Jurnal Akuntansi, 1, 153.

Katsi, P. E. (2015). Accounting Systems Usage By Small Businesses in Maluti-aPhofung, Free State considered. Indian Journal of Finance and Banking; ISSN 25746081,(September).

Retrievedfromhttps://repository.nwu.ac.za/handle/10394/15327

Khan, S. a, Lederer, A. L., \& Mirchandani, D. a. (2013). Top Management Support, Collective Mindfulness, and Information Systems Performance. Journal of International Technology E Information Management, 22(1), 95-122. Retrievedfromhttp://search.ebscohost.com/login.aspx?direct=true\&db=bth $\& A N=95588447 \&$ site $=$ ehost-live.

Kouser, R., Awan, A., \& Shahzad, F. (2011). Firm Size, Leverage and Profitability: Overriding Impact of Accounting Information System. Business $\mathcal{E}$ Management Review, 1(10), 58-64.

Kurnia, D., \& N Fitriani. (2015). Pengaruh Return on Asset (ROA)dan Return on Equity (ROE)Terhadap Harga Saham Pada Perusahaan Sektor Pembiayaan yang Terdaftar Di BEI Tahun2011. 1, 65-81.

Mangeta, S. A., Mangantar, M., Baramuli, D. N., Manajemen, J., Sam, U., \& Manado, R. (2019). Analysis Of Return On Equity (ROE), Net Profit Margin (NPM), and Return On Assets (ROA) On Property Stock Prices On The Idx ( Period 2013-2017). Jurnal EMBA, 7, 3768-3777.

Megasari, R. P. (2015). Analisis Rasio Keuangan Untuk Menilai Kinerja Keuangan Perusahaan Manufaktur Yang Go Public Di BEI (Studi Pada Sektor Industri Food and Baverages Di Bursa Efek Indonesia Periode Tahun 2010-2012). Jurnal Akuntansi.

Muhlis. (2019). Pengaruh Return On Asset (ROA), Debt to Equity Ratio (DER) Dan Earning Per Share (EPS) Terhadap Harga Saham (Studi Empiris Pada 
Perusahaan Manufaktur Subsektor Logam Dan Sejenisnya Yang Terdaftar Di BEI Periode 2012-2016). Jurnal Akuntansi.

Nalurita, F. (2015). The Effect of Profitability Ratio, Solvability Ratio, Market Ratio on Stock Return. Business And Entrepreneurial Review.

Paradita, P. ., Damayanti, M., \& Ifa, K. (2017). Pengaruh ROA , DER , OPM , EPS dan Current Ratio Terhadap Harga Saham Perusahaan Industri Barang Konsumsi Yang Terdaftar Di Bursa Efek Indonesia Periode Tahun 2015. 215.

Putri, I. A. (2015). Pengaruh Intellectual Capital (IC) Terhadap Return Saham Dengan Kinerja Keuangan Sebagai Variabel Intervening (Studi Pada Perusahaan Transportasi Yang Terdaftar Di BEI Tahun 2011-2013). Jurnal Akuntansi.

Rachmawati, Y. (2018). Pengaruh Inflasi Dan Suku Bunga Terhadap Harga Saham Pada Perusahaan Perbankan Yang Terdaftar Di LQ45 Bursa Efek. Jurnal Akuntansi.

Rosikah. (2018). Effects of Return on Asset, Return On Equity, Earning Per Share on Corporate Value. The International Journal of Engineering and Science, 7, 614.

Rostami. (2016). The Effect of Corporate Governance Components on Return on Assets and Stock Return of Companies Listed in Tehran Stock Exchange. Procedia Economics and Financ, 36, 137.

Salim, A., Abdurrahman, \& Afi, R. . (2016). Effect of Dividend per share (DPS), Net profit margin (NPM) and Return on Equity (ROE) on Share Price (Manufacturing Industry Company listed on Indonesia Stock Exchange for 2012-2015). E - Jurnal Riset Management, 190-202.

Sianipar, A. (2005). Pengaruh Faktor Fundamental Terhadap Harga Saham Industri Perbankan Di Inonesia. Jurnal Akuntansi.

Sondakh, P. (2019). Pengaruh Struktur Modal (ROA, ROE dan DER) Terhadap Nilai Perusahaan (PBV) Pada Perusahaan Sektor Properti Yang Terdaftar DI BEI (Periode 2013-2016). Jurnal Akuntansi.

Stoner, A. ., \& Sirait, J. (1994). Manajemen Investasi.

Sugiyono. (2013). Metode Penelitian Pendidikan Pendekatan Kualitatif Kuantitatif. Bandung: Alfabeta.

Zaenal, A. (2005). Teori Keuangan dan Pasar Modal. 